\title{
The career development processes of women refugees in South Africa: An exploratory study
}

Authors:
Tatenda Nyabvudzi ${ }^{1}$
Willie T. Chinyamurindi
Affiliations:
${ }^{1}$ Department of Industrial
Psychology, Faculty of
Management and Commerce,
University of Fort Hare,
Alice, South Africa
2 Department of Business
Management, Faculty of
Management and Commerce,
University of Fort Hare,
Alice, South Africa
Corresponding author:
Willie Chinyamurindi,
chinyaz@gmail.com
mobile device
to read online.
Dates:
Read online:
Received: 22 Mar. 2019
Accepted: 01 July 2019
Published: 20 Aug. 2019
How to cite this article:
Nyabvudzi, T., \&
Chinyamurindi, W. T. (2019).
The career development
processes of women
refugees in South Africa: An
exploratory study. SA Journal
of Industrial Psychology/SA
Tydskrif vir Bedryfsielkunde,
45(0), a1662. https://doi.
org/10.4102/sajip.v45i0.1662
Copyright:
C) 2019. The Authors.
Licensee: AOSIS. This work
is licensed under the
Creative Commons
Attribution License.

Orientation: There is an observed global movement of labour (freely and forcibly). South Africa emerges as a popular receiving ground for refugees. Within the career psychology literature, scant attention is given to understanding the career development concerns, post-settlement, of women refugees in the host country.

Research purpose: The study explored the career development processes of women refugees, post-settlement, in South Africa as a host country.

Motivation for the study: Calls have been made within local and international literature for studies that give attention to understanding the career development processes of minority groups.

Research approach/design and method: Using a narrative inquiry approach, this study explored the career development processes of women refugees using a sample of 20 women refugees in South Africa. Relying on a snowball sampling procedure to recruit the participants, in-depth interviews were utilised as a data collection technique.

Main findings: Drawing on participants' narratives, the findings illustrate how women refugees have been more concerned with fulfilling a short-term desire for survival and acquiring basic commodities at the expense of a longer focus of advancement and career progression. This is mainly compounded by the structural constraints that limit both their career development and their lived experiences. Issues exclusive to the women refugees are also revealed. Overall, the results illustrate how all the aforementioned factors intersect as barriers that hinder women refugees in developing their careers.

Practical/managerial implications: The study provides information and strategies that policymakers in South Africa and other developing nations that are hosting refugees can use to facilitate the career development processes of women refugees.

Contribution/value-add: This study contributes to the growing body of knowledge focussing on career development of women refuges, a populace that previously received limited focus both locally and internationally.

Keywords: South Africa; women; refugees; career development; minority groups.

\section{Introduction}

Generally, women are perceived to be a vulnerable gender group compared to their male counterparts (Doubell \& Struwig, 2014). However, they are not inherently vulnerable as their vulnerability depends on multiple factors which extend beyond the fact that they are females (Islam, Ingham, Hicks, \& Manock, 2017). In the same way, refugees represent the most vulnerable and deprived fraction of the immigrant workforce (Magqibelo, Londt, September, \& Roman, 2016; United Nations High Comissioner of Refugees, United Nations Population Fund Agency \& Women's Refugee Commission, 2016). Having fled from their home countries, the moment refugees arrive in another country, they hope that they will be protected, they encounter adversity as they seek employment and navigate in this new and unfamiliar environment (Anderson, Stuart, \& Rossen, 2015; Newman, Brimrose, Nielsem, \& Zacher, 2018). There is an observation that refugees have the potential to face challenges linked to their gender, history and immigration status (Harry, Dodd, \& Chinyamurindi, 2019). Notably, women refugees are viewed as one of the most vulnerable groups of the immigrant workforce (Mason \& Pulvirenti, 2011; United Nations High Commission of Refugees, 2016). This study heightens focus on the issues faced by such a sample group.

The number of people seeking refuge and protection has escalated over the past decade (Newman et al., 2018). Reportedly, one in every 122 individuals across the world is seeking refuge 
(United Nations High Commission for Refugees, 2015) in countries that hold the promise of a safe and fulfilling life (Abkherz \& McMahon, 2017). One such country is South Africa, which is regarded as more popular in receiving refugees than any other African country (Harry, Dodd, \& Chinyamurindi, 2017; International Organisation for Migration, 2012). Since the transition to democracy in 1994, South Africa has been a favoured destination by a high number of refugees fleeing persecution in their home countries (Greyling, 2015). It has been observed in South Africa that refugees and migrants are vulnerable because of their status in the host country, yet their contribution can be immense (Harry et al., 2017; Mothibi, Roelofse, \& Tshivhase, 2015). Within the extant literature, calls exist to understand issues that affect refugees' integration into the mainstream society (Felicano \& Lanuza, 2017). Obtaining decent work is a significant contributor towards successful resettlement for refugees and, as such, this study explored the process of how refugee women navigate their careers when they arrive in a host country such as South Africa.

Often, career trajectories of women migrants receive less scholarly attention than migrant men (Kofman, 2012; Rydzik, Pritchard, Morgan, \& Sedgley, 2017) and despite the international observation that half of all migrants are women, the migration literature often frames the experience to be one that is gender neutral (De Leon Siantz, 2013; Kibiribiri, Moodley, Groves, \& Sebitloane, 2016; Noyori-Corbett \& Moxley, 2017). The researchers acknowledge that there has been a growing body of literature exploring careers of female self-initiated expatriates (Rydzik et al., 2017; Vagenshtein \& Yemini, 2016); however, less attention has been given to the plight of women refugees (Noyori-Corbett \& Moxley, 2017; United Nations High Commission for Refugees, 2015). The distinguishing factor is that one group initiates movement (e.g. self-initiated expatriates), whereas others like refugees are forced to leave their country.

A plethora of literature positions women refugees as a demographic group that is vulnerable often because of their difficult life trajectories (Abkherz \& McMahon, 2017; Magqibelo et al., 2016; Noyori-Corbett \& Moxley, 2017), an experience also noted in South Africa (Legal Resource Centre, 2015; United Nations High Commission of Refugees, 2016). The vocational obstacles and experiences among female refugees are not well-known as most refugee studies have presented women as dependants of men rather than economic providers (Kofman, 2012). It is only recently that the vocational literature has begun to focus on vulnerable groups such as women refugees (Abkhezr, McMahon, Glasheen, \& Campell, 2018; Newman et al., 2018).

Despite strides made through the enactment of legislation that seeks to protect refugees, like the South African Refugee Act 130 of 1998, challenges still exist that impede the career development processes not just of refugees, but especially those of women refugees (Abkherz \& McMahon, 2017; Magqibelo et al., 2016). This has led to calls, especially in South Africa, for studies that examine both the career transitions and the experiences of refugees (Elez, 2014). Within such nations, the career development processes of women refugees remain an underexplored phenomenon (Chinyamurindi, 2012, 2016). It is thus useful to explore the career development processes of women refugees in South Africa, with a particular focus on the role that structural constraints can play (Harry et al., 2017).

\section{Research purpose and objectives}

Calls exist within the empirical literature for studies that focus more on understanding the issues presented in this literature review, primarily on the career development processes of vulnerable groups such as women refugees (Campion, 2017). Thus, the main questions guiding the study were the following: how do the career development processes of women refugees in South Africa manifest, and what factors influence such processes when they arrive in host countries?

Additionally, very little is known about the impact of the global refugee crisis on the career dynamics and national labour markets (Richardson, Karam, \& Afiouni, 2016). With the reported influx of refugees in South Africa (Greyling, 2015), limited studies have investigated how refugees adapt to new life settings, career ecosystems and the impact of their migration in the management of their careers (Elez, 2014). Further, there is also a need to ascertain the role of structural constraints (including gender) in the lived experiences of refugees, especially within a developing nation context (Chinyamurindi, 2016). It is against this background that the study investigated the lived experiences of women refugees and the challenges they encounter in developing their careers in the South African context.

\section{Literature review}

\section{Theoretical lens}

This article is guided by a threefold theoretical framework. Firstly, feminist theory (Feminist Africa, 2015; Fernandes, 2013); secondly, intersectionality theory which emanates from black feminist theory (Crenshaw, 1991; McCall, 2005); and, lastly, the career construction theory (Savickas, 2005), which addresses unique issues that impact the career and life experiences to address women refugees' career development (Savickas, 2005). All three theoretical frameworks are discussed next.

\section{Feminist theory}

The feminist theory acknowledges subjectivities and women's struggles (Fernandes, 2013) and advocates for equal rights for women and equality of sexes (Lubis, Nasution, Rahimah, \& Zein, 2016). Feminist theorists call for the establishment of equal opportunities in all spheres of life, for instance in education, employment and voting (Hyndman \& De Alwis, 2008), and are primarily concerned with issues of gender differences (Feminist Africa, 2015). This study takes a feministic standpoint by promoting women refugees' voices through their career trajectories as their experiences are often 
muted within refugee studies (Hyndman \& De Alwis, 2008; Noyori-Corbett \& Moxley, 2017; Rydzik et al., 2017). As a feminist exploration of refugee women's experiences, this article builds on the career development literature by incorporating the voice of an often-neglected populace.

\section{Intersectionality theory}

Intersectional feminism is deeply rooted in black feminist thoughts that advocated and analysed the multiple oppressions of race, class and gender (Carbado, Crenshaw, Mays, \& Tomlinson, 2013; Choo \& Ferree, 2010). The basis of intersectional feminism is to examine overlapping systems of oppression and discrimination that certain groups of women encounter on the basis of gender, race and class simultaneously (Mitchell, 2013). Similarly, Cook, Heppner and O'Brien (2002) ascertained that the career development processes of women are more complex than those of men because of a combination of internal and external barriers exclusive to women. The intersectionality theory helps to understand the multiple sources of refugee women's experiences as well as the impact of the interconnections in the career development of the women refugees.

\section{Career construction theory}

This study also focussed on the career construction theory in helping to understand how careers develop and adapt over time in response to role transitions over a given lifespan (Di Fabio \& Maree, 2013; Savickas, 2005). This theory has been used in previous research with refugees as a research sample (Campion, 2017). Within the career construction theory, value is placed on the role of career adaptability through an individual's readiness and resources for coping with varying career transitions (Savickas, 2005; Xie, Xia, Xin, \& Zhou, 2016). The underlying focus is that career adaptability influences career decision-making, career engagement and satisfaction (Perera \& Mcllveen, 2014). This positions the career construction theory as beneficial in understanding career development experiences as it focusses on individuals and their response to varying changes, especially those in their environment (Maree, 2015; Savickas, 2005).

\section{Empirical literature}

The empirical literature attributes the successful integration of refugees mostly to the effects created by the interaction of pre- and post-migration factors (Tharmaseelan, Inkson, \& Carr, 2010). These pre- and post-migration factors have the potential to influence the success or failure of refugees in the host country (Berger, 2004; Harry, Dodd, \& Chinyamurindi, 2017; Yakushko, Backhaus, Watson, Ngaruiya, \& Gonzalez, 2008). Pre-migration factors include education, vocational experience, knowledge and skills that one acquired before migrating in their home country (Tharmaseelan et al., 2010). Post-migration factors comprise occupational demography, culture of the host country as well as structural constraints (Codell, Hill, Woltz, \& Paul, 2011; Tharmaseelan et al., 2010). Often it is the role of their gender that limits these refugees' lived experiences in the resettlement phase (Noyori-Corbett \& Moxley, 2017).

Notably, the first universal instrument to outline the definition of a refugee, the 1951 Convention, excluded the experiences of women from the scope of the convention (Arbel, Dauvergne, \& Millbank, 2014). Feminists argue that the convention is silent on the forms of harm and disadvantages specific to women and their experiences may be understood as falling outside the definition of persecution (Fletcher, 2006), and this has seen some women's asylum applications being rejected (Edwards, 2010). Consequently, failure to obtain a legal status impedes their rights stipulated in the South African Constitution, including the right to work.

Previous studies in South Africa have framed the role of gender and structural constraints in the career development processes of women, mostly from an organisational perspective (Chinyamurindi, 2016; Crush, 2011; Doubell \& Struwig, 2014). Internationally, this also appears to be a trend, with the focus being on the role that quests for balance and responses to societal expectations play in career development (Allen, French, \& Poteet, 2016; Bleinjenbergh, Gremmen, \& Peters, 2016; Campion, 2017). Ostensibly, migrant women often devalue their qualifications and take service jobs like domestic work as a measure to gain entry into the labour force. In some cases, this is because of some employers and organisations not recognising the refugees' right to work (Magqibelo et al., 2016), the desire to fend for family, as well as already existing challenges of forced migration (Chinyamurindi, 2012; Harry et al., 2017; Saunders, 2017). Often, women refugees fail to secure employment due to a combination of low language skills, poor or no formal qualifications (Nicolescu, 2017; Willott \& Stevenson, 2013), in some cases xenophobic attacks because of the threat they pose to citizens' socio-economic success (Amataika, 2013), as well as traditional gender stereotyping which sees the society upholding that certain roles and duties belong to women (International Labour Organization, 2015; Sandberg, 2013).

\section{Research design Research approach and strategy}

With the predominantly explorative nature of this study, the authors followed a qualitative and interpretivist research approach.

The interpretivist paradigm promotes the value of qualitative data in seeking knowledge (Yilmaz, 2013), exploring unique realities faced by participants and understanding human experiences through the participants' voices, activities, beliefs and behaviour (Shaik, 2016).

The study further operated from the feministic premise of giving women the voice of constructing their realities (McMahon, Watson, Chetty, \& Hoelson, 2012); thus, the interpretive paradigm was best suited to the exploration. 
Ontologically, the authors believe that reality is socially constructed and that there are as many realities as there are people constructing them (Scotland, 2012). The authors thus do not claim any neutrality in the process of meaningmaking but adopted strategies to ensure data quality. The authors' epistemological perspective is based on real-world phenomena (Scotland, 2012) where the social world can be understood from participants' perspective (Creswell, 2013).

\section{Research method}

\section{Sampling}

The study used a purposive and snowball sampling technique to identify research participants (Abkherz \& McMahon, 2017). This technique allowed deliberately access to a reliable database that is not easily accessible (Woodley \& Lockard, 2016).

A total of 20 women refugees were recruited, who shared their career development narratives. The research participants consisted of women refugees from African countries, notably the Democratic Republic of Congo (DRC) (35\%), Somalia (30\%), Uganda (10\%), Burundi (15\%), Cameroon $(5 \%)$ and Kenya (5\%). Table 1 details the profiles of the participating women refugees.

\section{Research setting, entrée and researcher roles}

The researchers strategically located the study in the city of Port Elizabeth in the Eastern Cape province, as this was a well-known receiving ground for refugees settling in South Africa. The researchers approached the refugee reception centre in Port Elizabeth, Eastern Cape province, and asked for permission to access refugee women who take part in their activities. Once contacts from the agencies were established, the researcher relied on referrals from these contacts.

The choice of the research setting was based on the purposive nature of the study. Permission to access participants was obtained from the refugee reception centre as well as consent from individuals who volunteered to take part in the study. The first author who worked as an intern at the refugee reception centre facilitated the data collection and transcription. The second author participated in the full data analysis and completion of the manuscript.

\section{Data collection}

Data were collected primarily through the use of face-to-face, semi-structured in-depth interviews. The interviewer worked as an intern at a refugee reception centre and conducted all 20 interviews over the course of 7 months (approximately three interviews per month). Because of this lengthy period, the researchers had enough time to try to recruit more participants and transcribe the data. Interviews were conducted in a closed room at the refugee centre to ensure complete confidentiality.

\section{Data recording}

Interviews were audio-recorded and transcribed verbatim and stored on password-protected computers accessible only to the researchers. Recording interviews protected the researcher against bias and provided a true record of what was said during the interviews (Cormark, 2000).

TABLE 1: Participants profile.

\begin{tabular}{|c|c|c|c|c|c|}
\hline Pseudonym & Country of origin & Pre-migration career & Post-migration career & Further studies in South Africa & Career aspirations \\
\hline Anna & Somalia & Hawker & Hawker & None & None \\
\hline Brenda & Somalia & Grade 12 & Translator & Home Based Carer Course & Home Based Carer \\
\hline Clara & Congo & Minor & Hawker & Engineering Degree & Engineer \\
\hline Deon & Somalia & Minor & Translator & Home Based Care course & Air Hostess \\
\hline Edith & Somalia & Primary School Education & Spaza shop owner & None & Business/ Hawking \\
\hline Flora & Burundi & Grade 10 & $\begin{array}{l}\text { Vendor; Home Based } \\
\text { Carer }\end{array}$ & $\begin{array}{l}\text { Home Based Care; First Aid; HIV } \\
\text { Counselling; Childcare. }\end{array}$ & Lawyer \\
\hline Gayle & Congo & $\begin{array}{l}\text { Comedian; Studying towards a Teaching } \\
\text { qualification }\end{array}$ & Hairdresser & None & Teaching; Acting: Comedian \\
\hline Hilda & Cameroon & Bookkeeping Diploma; Cashier & Hairdresser & None & $\begin{array}{l}\text { Work in line with her } \\
\text { qualifications }\end{array}$ \\
\hline Irene & Burundi & Grade 8 scholar & Hairdresser & $\begin{array}{l}\text { Heath Care; Counselling; After Care; } \\
\text { HIV and TB Counselling; Interpreting }\end{array}$ & $\begin{array}{l}\text { Work in line with her } \\
\text { qualifications }\end{array}$ \\
\hline Jacqueline & Uganda & Diploma in Secondary education & Hawker & $\begin{array}{l}\text { B Comm. Human Resources } \\
\text { (incomplete) }\end{array}$ & Teaching Career \\
\hline Karen & Congo & Law (3rd year) & Nanny; Translator & Home Based Care; English Course & To complete her Law studies \\
\hline Linda & Congo & Beauty Therapy Certification; Till Operator & Vender & None & Beauty Therapy \\
\hline Mary & Somalia & Minor & Researcher; Translator & Matric; Social work certificate & Lawyer \\
\hline Nelly & Kenya & Grade 12 & Vendor & None & None \\
\hline Otillia & Burundi & Grade 6 & Hairdresser & Till Operator Course & None \\
\hline Prisca & Uganda & $\begin{array}{l}\text { Foundation phase certificate; Primary } \\
\text { School Teacher; Running a Pre-School }\end{array}$ & None & None & None \\
\hline Queen & Congo & Business Economics certificate; Teacher & Hairdresser & None & Teacher \\
\hline Ruth & Somalia & Diploma in Community Development & Vendor; Spaza shop owner & None & None \\
\hline Sally & Congo & Secondary Education; Professional Tailor & Tailor & None & Tailor \\
\hline Trish & Congo & Matric; Secretariat Course; Secretary & Hairdresser & English courses & $\begin{array}{l}\text { Further her studies and work } \\
\text { as an Administrator }\end{array}$ \\
\hline
\end{tabular}

Note: Demographics of participants obtained during the data collection process.

B Comm., Bachelor of Commerce; HIV, human immunodeficiency virus; TB, tuberculosis. 


\section{Strategies to ensure data quality}

Four steps were followed to ensure data quality. Firstly, interview questions (refer to Appendix 1) were pre-tested with a sample of 10 female international students as a way to pre-test the measuring instrument. The researchers acknowledge here that international students may not necessarily be refugees, but they are close to fitting the experiences refugees may go through, especially by not being from South Africa and also seeking ways to adjust in a foreign land. The latter are traits viewed as common to those of refugees (Abkherz \& McMahon, 2017). Secondly, to ensure credibility of data, all the interview data were recorded and transcribed verbatim within $24 \mathrm{~h}$ of the interview. Thirdly, after the data transcription process, a copy of the transcripts was sent to participants by mail or email to verify the accuracy thereof. This process took some time and was usually followed up by a telephone call. Finally, before and during the study, reflexivity was conducted to safeguard objectivity and avoid researcher bias, as well as to ensure sensitivity on how data were collected, analysed and represented (Taylor, Gibbs, \& Lewins, 2005). In doing so, we also took comprehensive notes at all critical stages of the research for additional depth and quality.

Furthermore, to enhance transferability and dependability of the findings, a detailed description of the research methods, setting and sample size was provided. To ensure data authenticity and credibility, voluntary participation and rapport building were maintained to enhance open and honest responses. The interviewer being a woman and introducing herself as a foreign national made the participants feel at ease and communicate openly without being inhibited about their language skills. Confirmability of the findings was enhanced by using the participants' quotes in presenting our findings.

\section{Data analysis}

The interviews were all exported into QSR International's NVivo 11, a useful data analysis and management software package for dealing with masses of text, graphic, audio and video data (Reuben \& Bobat, 2014). Narrative analysis procedure based on three levels of meaning-making was adopted, as used in previous narrative research (for example Chinyamurindi, 2012; 2016; McCormack, 2000). The researchers used level 1 to gain a good understanding of the career development experience of each of the women refugee's stories. This was done by re-reading each interview and listening to audio recordings. This process allowed for the identification of "markers" within the stories and developing an in-depth understanding of each interview (McCormack, 2000; Thornhill, Clare, \& May, 2004). This process consisted of an evaluation of each transcript and grouping of each story based on the narrated experiences of the women refugees. The researchers then proceeded with level 2, which was achieved through classifying responses from participants into meaningful and useful categories (Nachmias \& Nachmias, 1996). Classifying responses helped to derive themes and identify connecting themes from participants (Denzin \& Lincoln, 2000; Nachmias \& Nachmias, 1996). Quotes and stories were then used to provide an analysis of the themes gathered. Finally, on level 3, the researchers analysed the content of the gathered narrative accounts and themes by identifying themes and using quotes based on consistencies across the participant stories (McCormack, 2000).

\section{Ethical consideration}

Firstly, an ethical clearance was applied for and granted by the participating institution. Secondly, permission was sought from the refugee agencies. Furthermore, the research followed an ethical framework that entails voluntary participation, informed consent, the right to withdraw, anonymity and confidentiality.

\section{Results}

Three main findings emerged from the data analysis. Firstly, it appears that the women refugees were more concerned with their desire for short-term survival through acquiring basic commodities than a long-term focus to advance and develop their careers. Although most of the participants narrated their vocational aspirations, their careers are currently daunted by their refugee status, socio-histories and gender. Informal employment emerged as the most viable option for them, allowing them to at least meet their day-today survival needs, shifting their attention from the longterm focus to build careers to meeting basic needs for survival. This could be because of the changed standard of living in South Africa as opposed to their home countries. Secondly, we found the role of personal and structural constraints to be informing the career development processes as well as the lived experiences of the women refugees. Finally, gender was illustrated as playing a role in the women's career development and in their lived experiences.

\section{Short-term desire for survival}

Participants in the study expressed a desire for short-term survival as opposed to a long-term orientation to issues that affected them. This short-term desire was manifested through their expression to acquire and fulfil more of their physiological needs (mainly food, shelter and security) instead of being engaged in the long-haul on a career path. One participant, Brenda, pointed out her desperation to meet these everyday needs:

'When I got to South Africa from my home country, I studied a home based care course, not because I liked the course, but rather it was the cheapest and quickest I could get a job. The issue was to pay my bills and provide for the family. Though I was not a fan of the course and job.' (Brenda, Somalian, Translator \& General Labourer)

The desire for meeting immediate short-term needs appeared to press on the lived experience of women refugees and affected their vocational choices. One participant, Prisca, also narrated her frustration of lack of a long-term career focus 
whilst opting for a short-term solution to acquire basic commodities:

'The struggle is on, I may know what I want, but I am more into what makes economic sense for now which is to have money to pay rent and survive for now. I want to think the future, but things are really challenging now affecting me and my baby ... That's what the focus is for now, watching out for me and my baby.' (Prisca, Ugandan, Unemployed)

Part of the challenge and a possible explanation for the shortterm survivalist mentality could be attributed to a language barrier. Refugees often find it difficult to express themselves in English, let alone the local South African languages. As a result of this, refugees like Deon prefer to stay in jobs with little or no career progression because of the language issue. Deon stated that within these jobs, she is able to have some money to meet his basic needs:

'Language is a challenge for refugees, especially us from Somalia, and also adjusting to the way of life here in South Africa. So we as Somalians are more focussed on careers where we have minimal or no progression whilst making a basic living to pay rent and buy food.' (Deon, Somalian, Translator)

The majority of the participants reported that they could not obtain employment as a result of their limited English proficiency and low level of formal education when they arrived in South Africa. Over time their language proficiency has improved and some have even obtained a formal qualification to gain entry into the labour force although they continue to face formidable barriers in obtaining employment. Mary who has a Social Work qualification narrated her ordeal as follows:

'My refugee status has affected big time ... I have been turned down in positions 1 am qualified for because of refugee status. This makes me very helpless.' (Mary, Somalian, Researcher \& Translator)

Some refugees admitted having established careers in their home countries. For instance, Jacqueline came from Uganda where she worked as a teacher, whilst in South Africa she is currently a domestic worker and also sells goods on the streets. Her desire is to further pursue her interest in a teaching career. However, this has challenges which make her focus more on the short-term options:

'It is very difficult to work here and sustain a long-term career focus. As refugees, we have dreams we wish realised. The journey to those dreams in a foreign country is not always easy. So leading to those dreams, if ever they get realised, one must find ways in the present to earn an income and sustain themselves.' (Jacqueline, Ugandan, Hawker)

In essence, a short-term focus for survival was prioritised by the women refugees who took part in this study, at the expense of a more long-term option, where a career path is envisioned. This short-term focus was mostly because of constraints that pressed on the women refugees and mostly beyond their control. These constraints placed a limit on the ability to enact career choices albeit the desire exists. Thus, the second finding from the analysis of the views of the women refugees reveals the structural constraints affecting both their career and their lived experiences.

\section{Structural constraints as limitation to career and lived experiences}

The results indicate that the structural constraints that affect women refugees are mostly socio-economic in nature. These constraints not only limit individual involvement in their careers, but also their lived experiences.

The pressing issue narrated by most of the participants is xenophobia. The xenophobic attacks do not only affect their vocational lives but also their personal lives, and this hinders their settlement process. One participant narrated her experience as follows:

'You just don't belong. Like there is an intense hatred for foreigners. At work one time I was shouted at by my colleagues who are South Africans. Basically, I was told to go back to my home country, and they don't want me here.' (Flora, Burundian, Home Based Carer)

Xenophobia affects career development of refugees because of a number of factors. Firstly, the local citizens see refugees as a threat to the economic security by stealing their jobs. Secondly, some employers are ignorant and reluctant to employ refugees because of their documentation:

'It is us against them. Everywhere you go, our foreign status and identity is a feature. Once you present refugee documentation to prospective employers, it's a no for them. This is usually followed by an intense hatred at what it means to be foreigner, a strangeness the locals detest.' (Ruth, Somalian, Spaza Shop Owner)

The participants narrated how they experience negative prejudices when seeking employment and how their applications are rejected because of their nationality. This has resulted in their lack of social and economic power.

'There was a vacant position and I was being considered for the post but when a new director was appointed and she consulted with other people only to learn that I am a refugee, they all reportedly said that I am just a refugee and the best position I can have is being an interpreter.' (Mary, Somalian. Researcher \& Translator)

Another participant narrated her ordeal as follows:

'A refugee in South Africa has no power whatsoever. For instance, I went to apply for a job and the employer could not recognise and understand my refugee status and the accompanying documents.' (Trish, Congolese, Hairdressor)

Taking all the aforementioned narratives into account, it can be said that most of the women refugees have resorted to informal economy for their livelihood. However, they continue to encounter formidable barriers that continue to affect their well-being. One participant expressed how document accessibility hinders informal trading:

'I wanted to rent a place for my business but it was hard. They wanted proof of address and bank statement which I could not have because the bank did not allow me to open an account with my identity document.' (Jacqueline, Uganda, Hawker) 
Another participant also recalled an incident where foreign traders were attacked by the local citizens:

'Foreigners face challenges in this country. A few years ago we noticed the xenophobic challenges especially here in Port Elizabeth. Foreigners were attacked and their property either looted or destroyed. South Africans at least to me just hate as foreigners, especially African foreigners.' (Queen, Congolese, Hawker)

Through the data analysis, some issues that relate to gender as affecting the career development processes and the lived experiences of the women refugees were also identified.

\section{Issues exclusive to women refugees}

The women refugees who took part in this study provided a frank disclosure of what it means to be a woman and also a refugee. In most cases, aspects of earning a living accompanied these experiences and comparison was made with their male counterparts:

'My situation would be different if I was a male; this world is a man's world. Male refugees often get a priority ahead of us females. They are perceived to be stronger than us women.' (Clara, Congolese, Hawker)

Some of the women, like Edith, narrated challenging experiences as part of their lived experiences that have subsequently affected them, for instance, rape:

'I used to have a shop, but I was robbed two times. I am now struggling to get a job or at least raise funds to open a shop again. One day robbers arrived at the shop and raped me. Since then I have never been the same and also have psychological problems.' (Clara, Somalian, Hawker)

Other challenges concerned seeking to strike a balance between commitments at work and taking care of their families. This was a quest for work-life balance, as confirmed by Brenda:

'I want to expand my career, but I know I cannot. I do need a job and at best a career but this is not possible. I am a mother and have to look after my baby. I am the mother and father together for my child.' (Brenda, Somalian, Translator \& General Labourer)

\section{Discussion}

The purpose of this article was to explore the career development processes of women refugees in South Africa. The results of the current study contribute generally to an understanding of the issues that refugees face in the resettlement phase, especially within developing countries like South Africa, which is witnessing an increase in refugees. Narrating their career trajectories, refugee women cited markers of their personal environment factors, migration status and gender identity to explain the hardships they face in navigating their careers.

It is evident that the career development process of the women refugees is shaped by various factors, such as language proficiency and education, emanating from premigration career capital (Tharmaseelan et al., 2010), structural constraints such as xenophobia (Di Fabio \& Maree, 2013) as well as gender (Doubell \& Struwig, 2014). Of importance is that these challenges are not mutually exclusive but are interconnected and inextricably intertwined with their gender, history and immigration status (Mitchell, 2013).

As conceptualised by Tharmaseelan et al. (2010), the narratives that emerged in this study emphasise that career development is moderated by both pre- and post-migration factors. Firstly, as per prior studies (Nicolescu, 2017; Willott \& Stevenson, 2013), refugees struggle to integrate into the host country because of language barriers. Secondly, organisations fail to recognise their documentation and their right to work (Magqibelo et al., 2016). Xenophobia, a recurrent and prevalent culture in the South Africa (Amataika, 2013), continues to see refugees vulnerable in their place of refuge.

Our work advances empirical work in South Africa, which shows refugees to be facing challenges in the resettlement phase (Gordon, 2015; International Organisation for Migration, 2012). Uniquely, our findings show that women refugees have a basic need for survival, rather than a long-term career focus. This desire is actuated by the situation and experience of being a refugee, which is complex and marred by uncertainty. Subsequently, this justifies the short-term focus as a basis for survival. Linked to this idea of a short-term focus is the role of structural constraints, especially those of a socio-economic nature, as hindering the growth of the women refugees. The latter finding places focus on the role of structural constraints in affecting the enactment of career choices (Di Fabio \& Maree, 2013). Our findings support previous empirical work that identified the role of the environment in the lived experiences of refugees and the possible limitations they impose (Baranika et al., 2017). This work extends work on the role of gender and the structural constraints of career development outside the organisational lens in South Africa (Chinyamurindi, 2016; Doubell \& Struwig, 2014).

\section{Implication for practice, theory and research}

This study makes four contributions to the literature. Firstly, by exploring the lived experiences and career issues affecting women refugees (the short-term focus, the structural constraints and the gender issues), we offer a nuanced view of refugee issues considering our socio-cultural milieu. Our results emphasise the vulnerable view of refugees, especially in the resettlement phase (Mothibi et al., 2015). Despite the view that the experience of being a refugee is gender neutral, our findings contradict this view and show struggles that potentially can exist within the resettlement phase of a refugee's life (Codell et al., 2011). In this regard, our study contributes to research on the career development processes of women refugees within a South African context, answering the call for studies that focus on such vulnerable groups (Chinyamurindi, 2016; Harry et al., 2017). Despite challenges that women refugees encounter, some remain hopeful and desire to have long-term career aspirations. This is evident from them (albeit the structural constraints) still seeking for survival and basic needs in view of a long-term aspiration. 
Secondly, through the findings of the research, our work intensifies understanding of a range of factors and their influence on career development as well as the lived experience (Abkherz \& McMahon, 2017). As depicted in Table 1, most of the women refugees indicated their vocational aspirations, but their growth is hindered by existing constraints. Ultimately, the only viable solution has been for the women refugees to take part in menial jobs, as a form of sustenance and to have a short-term career focus. This gives cadence to the theorising around the complexity of career issues affecting women (Cook et al., 2002). Importantly, our study illustrates how structural constraints impede individual experience and integration into society (Olliff, 2010). The previous theorising on such issues has been scant, especially within developing countries like South Africa. Thirdly, we advance the understanding of issues specific to women refugees and add to a collection of literature on the same topic internationally and within developing countries (Abkherz \& McMahon, 2017; Harry et al., 2017). To this, we also illustrate the intersection of structural constraints and gender to the lived and career experiences of women refugees. All these factors could assist in how refugees reestablish their lives in a host country.

The research heightened focus on the role of a multistakeholder approach in assisting women refugees in their resettlement. Through barriers identified in this study, stakeholders can propose policy and practical interventions that assist women refugees. For instance, participants of this study reported barriers faced when trying to find work and they exposed the ignorance and prejudiced nature of society towards immigrants. It could be useful for organisations dedicated to assisting refugees to work with relevant government departments in educating organisations and employers to understand issues affecting refugees. Furthermore, educational and awareness programmes can be introduced to a targeted and broader society, given the challenges of xenophobia. Government support could also assist in all these efforts by creating an enabling environment that allows for the prosperity, not just of locals, but also of refugees.

\section{Limitations and future research}

Because of the explorative nature of our study, the research purposely consists of a limited number of women refugees, whereas there are also male refugees. The excerpts presented in the study provide rich data that are useful in creating interventions for career development of this neglected population group. Future research should also compare career development processes of men and explore the gender perspective from another angle.

The researchers believe that a good rapport was established owing to the feministic nature and acquaintances that the interviewer had with the participants. However, a possible drawback that cannot be overlooked is that the language utilised during the interviews is a second language to both the interviewer and participants. Certainly, there were moments of misunderstanding during the interviews and a few questions such as 'Do you think women's career development processes are different from those of men?' and 'Is your career developing as you anticipate?' went unanswered during one (Interview with Anna) of the interviews as they were not fully understood by the participant. However, the fact that the interviewer introduced herself as a foreigner and non-native English speaker enabled the participants to speak more openly without being inhibited about their language skills. The interviewer was also in a better position to understand some speakers who made errors as she is also used to hearing similar mistakes from her colleagues and some that she also makes herself. As such it is possible that each of the stories if told in a different context and another language would yield different meanings.

\section{Conclusion}

The study focussed on how career development processes of women refugees in South Africa are manifest, as well as the factors and barriers that influence such processes. The research drew attention to both the gendered nature of society and the structural constraints that impede the lived experiences of refugees, especially within the context of a developing country. It was evident from the women participants in the study that the experience of being a refugee has affected them, often resulting in irony. Firstly, the women refugees appear to have lost not only the source of livelihood they had in their home countries, but also the enactment of a career choice. However, an advantage is their experience of the environment which is favourable compared to their home countries. In essence, this favourable environment made South Africa a desired destination.

\section{Acknowledgements}

The researchers acknowledge the participating students who made this study worthwhile.

\section{Competing interests}

The authors declare that they have no financial or personal relationships that may have inappropriately influenced them in writing this article.

\section{Author's contributions}

W.T.C. supervised T.N. for her PhD degree. The article was a joint effort between the supervisor and the student.

\section{Funding}

This research received no specific grant from any funding agency in the public, commercial or not-for-profit sectors.

\section{Data availability statement}

Data sharing is not applicable to this article as no new data were created or analysed in this study. 


\section{Disclaimer}

The views and opinions expressed in this article are those of the authors and do not necessarily reflect the official policy or position of any affiliated agency of the authors.

\section{References}

Abkherz, P., \& McMahon, M. (2017). Narrative career counselling for people with refugee backgrounds. International Journal for the Advancement of Counselling, 39(2), 99-111. https://doi.org/10.1007/s10447-017-9285-z

Abkhezr, P., McMahon, M., Glasheen, K., \& Campell, M. (2018). Finding voice through narrative storytelling: An exploration of the career development of young African females with refugee backgrounds. Journal of Vocational Behaviour, 105, 17-30. https://doi.org/10.1016/j.jvb.2017.09.007

Allen, T. D., French, A. F., \& Poteet, M. L. (2016). Women and career advancement. Organizational Dynamics, 45(3), 206-216. https://doi.org/10.1016/j.orgdyn. 2016.07.006

Amataika, A. D. (2013). Local Government in South Africa since: Leadership, democracy, development and service delivery in a post-apartheid era. Durham: democracy, development
Carolina Academic Press.

Anderson, J. R., Stuart, A., \& Rossen, I. (2015). Not all negative: Macro justice principles predict positive attitudes towards asylum seekers in Australia. Australian Journa of Psychology, 67(4), 207-213. https://doi.org/10.1111/ajpy.12085

Arbel, E., Dauvergne, C., \& Millbank, J. (Eds.). (2014). Gender in refugee law: From the margins to the centre. London: Routledge.

Baranika, L. E., Hurst, C. S., \& Eby, L. T. (2017). The stigma of being a refugee: a mixedmethod study of refugees' experiences of vocational stress. Journal of Vocational Behaviour, 105, 116-130. https://doi.org/10.1016/j.jvb.2017.09.006

Berger, R. (2004). Immigrant women tell their stories. New York: Haworth Press.

Bleinjenbergh, I., Gremmen, I., \& Peters, P. (2016). Timing ambition: How organisational actors engage with the institutionalised norms that affect the career development of part-time workers. Scandinavian Journal of Management 32, 179-188. https://doi.org/10.1016/j.scaman.2016.08.004

Campion, E. D. (2017). The career adaptive refugee: Exploring the structural and personal barriers to refugee resettlement. Journal of Vocational Behaviour, 105, personal barriers to refugee resettlement. Journal

Carbado, D. W., Crenshaw, K. W., Mays, V. M., \& Tomlinson, B. (2013). Intersectionality: Du-Bois review. Social Science Research on Race, 10, 303-312. https://doi.org/ 10.1017/S1742058X13000349

Chinyamurindi, W. T. (2012). Stories of career change amongst distance learners in South Africa. South African Journal of Human Resources Management, 10(2), $1-11$.

Chinyamurindi, W. T. (2016). Using narrative analysis to understand factors influencing career choice amongst a sample of distance learning students in South Africa. South African Journal of Psychology, 46(3), 390-400. https://doi.org/10.1177/ 0081246315623662

Choo, H. Y., \& Ferree, M. M. (2010). Practicing intersectionality in sociological research: A critical analysis of inclusions, interactions, and institutions in the study of inequalities. Sociological Theory, 28(2), 129-149. https://doi.org/10.1111/ j.1467-9558.2010.01370.x

Codell, J. D., Hill, R. D., Woltz, D., \& Paul, A. G. (2011). Predicting meaningful employment for refugees: The influence of personal characteristics and developmental factors on employment status and hourly wages. International Journal for the Advancement of Counselling, 33, 216-224. https://doi.org/ 10.1007/s10447-011-9125-5

Cook, E. P., Heppner, M., \& O'Brien, K. M. (2002). Career development of women of colour and white women: Assumptions, conceptualization, and intervention from an ecological perspective. The Career Development Quartely, 50(4), 291-305. https://doi.org/10.1002/j.2161-0045.2002.tb00574.x

Cormark, D. F. (2000). The research process in nursing. Oxford: Blackwell Science.

Crenshaw, K. (1991). Mapping the margins: Intersectionality, identity politics, and violence against women of women of color. Stanfors Law Review, 43(6), 1241-1299.

Creswell, J. W. (2013). Qualitative inquiry and research design: Choosing among five approaches. Thousand Oaks, CA: Sage.

Crush, J. (2011). Complex movements, confused responses: Labour migration in South Africa. SAMP Policy Brief. www.queensu.ca/samp/sampsouces/samppublications/ policybriefs/brief25.pdf.

De Leon Siantz, M. L. (2013). Feminization of Migration. A global health challenge Global Advances in Health Medicine, 2(5), 12-14. https://doi.org/10.7453/ gahmj.2013.065

Denzin, N. K., \& Lincoln, Y. S. (2000). Handbook of qualitative research. London: Sage.

Di Fabio, A., \& Maree, J. G. (2013). Career construction and life design: Heralding a new begining to career counselling in the 21st century. In A. Di Fabio, \& J. G. Maree (Eds.), Psychology of career counselling: New challanges for a new era. Hauppauge: Nova Science.

Doubell, M., \& Struwig, M. (2014). Perceptions of factors influencing the career success of professional and business women in South Africa. South African Journal of Economic and Management Sciences, 5, 31-43. https://doi.org/10.4102/ sajems.v17i5.514
Edwards, A. (2010). Transitioning gender: Feminist engagement with international refugee law and policy 1950-2010. Refugee Survery Quartely, 29, 21-45. https:// doi.org/10.1093/rsq/hdq021

Elez, T. (2014). Restoring hope: Responsing to career concerns of immigration clients. The Canadian Journal of Career Development, 13(1), 32-45.

Felicano, C., \& Lanuza, Y. R. (2017). An Immigrant Paradox? Contextual Attainment and Intergenerational Educational Mobility. American Sociological Review, 82(1) 211-241. https://doi.org/10.1177/0003122416684777

Feminist Africa. (2015). Feminism and Pan-Africanism. Feminist Africa. www.agi.ac.za/ journal/feminist-africa-20-2015-pan-africanism-and-feminism\#.

Fernandes, L. (2013). Transnational feminism in United States: Knowledge, ethics, power. New York: New York University Press.

Fletcher, A. (2006). The Real ID Act: Furthering Gender Bias in U.S. Asylum Law. Journal of Gender, Law \& Justice, 21, 111-131. https://doi.org/10.15779/Z381J9769V

Gordon, S. (2015). Xenophobia across the Class divide: South African attitudes towards foreigners 2002-2003. Journal of Contemporary African Studies, 33(4), 545-579. https://doi.org/10.1080/02589001.2015.1122870

Greyling, T. (2015). The expected well-being of urban refugees and asylum seekers in Johannesburg. Johannesburg. www.econrsa.org/publications/working-papers/ expected-well-being-urban-refugees-and-asylum-seekers-johannesburg.

Harry, T. T., Dodd, N. M., \& Chinyamurindi, W. T. (2017). Using narratives to understand the motivational factors and experience of being a self-initiated academic
expatriate in South Africa. South African Journal of Human Resource Management, expatriate in South Africa. South African Journal of Hum
$15,1-9$. https://doi.org/10.4102/sajhrm.v15i0.797

Harry, T. T., Dodd, N. M., \& Chinyamurindi, W. T. (2019). Telling tales: Using narratives and story-telling to understand the challenges faced by a sample of self-initiated
expatriates in South Africa. Journal of Global Mobility, 7(1), 64-87. https://doi. expatriates in South Africa. Journal
org/10.1108/JGM-05-2018-0024

Hyndman, J., \& De Alwis, M. (2008). Reconstructing the subject: Feminist politics of humanitarian assistance. In M. Haidukowskei-Ahmed, N. Khanlou, \& H. Moussa (Eds.), Not born refugee women: Contesting identities, rethinking practise (pp. 83-96). New York: Berghahn.

International Labour Organization. (2015). Women in business and management Gaining momentum. Geneva, Switzerland: International Labour Organisation.

International Organisation for Migration. (2012). International Organisation for migration's strategic framework for the Republic of South Africa, 2012-2016. Pretoria: International Organisation for Migration.

Islam, M. R., Ingham, V., Hicks, J., \& Manock, I. (2017). The changing role of women in resilience, recovery and economic development at the intersection of recurrent disaster, A case study from Sirajgang, Bangladesh. Journal of Asian and African Studies, 52, 50-67. https://doi.org/10.1177/0021909614560244

Jamshed, S. (2014). Qualitative research method interviewing and observation. Journal of Basic and Clinical Pharmacy, 5(4), 87-88. https://doi.org/10.4103/0976-0105.141942

Kibiribiri, E. T., Moodley, D., Groves, A. K., \& Sebitloane, M. H. (2016). Exploring disparities in prenatal care between refugees and local South African women. International Journal of Gynecology and Obsterics, 132, 151-155. https://doi. org/10.1016/j.ijgo.2015.07.007

Kofman, E. (2012). Gender and skilled migration in Europe. Cuadernos de Relaciones Laborales, 30(1), 63-89.

Legal Resource Centre. (2015). Rights and duties of asylum seekers and refugees in South Africa. Johannesburg: Legal Resource Centre.

Lubis, F. K., Nasution, I., Rahimah, I., \& Zein, T. (2016). The Women's Struggles for Islamic Feminism in the Shirazy'sAyat-Ayat Cinta (The Verses of Love). International Journal of Humanities and Social Science, 6(1), 106-113.

Magqibelo, L., Londt, M., September, S., \& Roman, N. (2016). Challenges faced by unaccompanied minor-refugees in South Africa. Social Work, 52(1), 73-89. https://doi.org/10.15270/52-1-480

Maree, J. G. (2015). Life themes and narratives. In P. J. Hurtung, M. L. Savickas, \& W. B. Walsh (Eds.), APA handbook of career intervention. Washington, DC: American Psychology Association.

Mason, G., \& Pulvirenti, M. (2011). Resilience and survival: Refugee women and violence. Current Issues in Criminal Justice, 23(1), 52. https://doi.org/10.1080/ 10345329.2011.12035908

McCall, L. (2005). The complexity of intersectionality. Journal of Women in Culture and Society, 30(3), 1771-1800.

McCormack, C. (2000). From interview transcript to interpretative story: Part 1. Viewing the transcript through multiple lenses. Field Methods, 26(1), 282-297. https://doi.org/10.1177/1525822X0001200402

McMahon, M., Watson, M., Chetty, C., \& Hoelson, C. (2012). Examining process constructs of narrative career counselling: An exploratory case study. British Journal of Guidance \& Counselling, 40, 127-141. https://doi.org/10.1080/030698 85.2011.646949

Mothibi, K. A., Roelofse, C. J., \& Tshivhase, T. (2015). Xenophobic attacks on foreign shop owners and street vendors in Louis Trichardt central business district. The Journal for Transdisciplinary Research in Southern Africa, 11(4), 151-162. https:// doi.org/10.4102/td.v11i4.51

Mitchell, K. (2013). Love in Action: Noting Similarities between Lynching Then and Anti-LGBT Violence Now. Callaloo, 36(3), 688-717

Nachmias, F. C., \& Nachmias, D. (1996). Research methods in the social sciences. New York: Worth Publishers.

Newman, A., Brimrose, J., Nielsem, I., \& Zacher, H. (2018). Vocational behavior of refugees: How do refugees seek employment, overcome work-related challenges, and navigate their careers? Journal of Vocational Behavior, 105 (2018), 1-5. https://doi.org/10.1016/j.jvb.2018.01.007 
Nicolescu, A. F (2017). The intergration of refugees into host country labor markets: Barriers and best practices in the EU. Journal of Identity and Migration Studies, 11(1), 118-134.

Noyori-Corbett, C., \& Moxley, D. P. (2017). Resettlement issues among Myanmar refugee women in the early state of a community-based developmental research project. Journal of Community Practice, 25, 1-25. https://doi.org/10.1080/10705 422.2017.1354240

Olliff, L. (2010). What works: Employment strategies for refugee and humanitarian entrants: Research report prepared by Refugee Council of Australia: June 2010. Sydney, Australia: RCOA.

Perera, H. N., \& Mcllveen, P. (2014). The role of optimism and engagement coping college adaptation: A career construction model. Journal of Vocational Behaviour, 84, 395-404. https://doi.org/10.1016/j.jvb.2014.03.002

Ponelis, S. R. (2015). Using interpretive qualitative case studies for exploratory research in doctoral studies: A case of Information Systems research in small and medium enterprises. International Journal of Doctoral Studies, 10, 535-550. https://doi.org/10.28945/2339

Reuben, S., \& Bobat, S. (2014). Constructing racial hierarchies of skill-experiencing affirmative action in a South African organisation: A qualitative review. South African Journal of Industrial Psychology, 40(1), 1-12. https://doi.org/10.4102/ sajip.v40i1.1158

Richardson, J., Karam, C., \& Afiouni, F. (2016). The impact of the global refugee crisis on the career ecosystem. Special Issue Call for Papers from Career Development International. http://www.emeraldgrouppublishing.com/products/journals/call_ for_papers.htm?id=6978.

Rydzik, A., Pritchard, A., Morgan, N., \& Sedgley, D. (2017). Humanising migrant women's work. Annals of Tourism Research, 64, 13-23. https://doi.org/10.1016/j. annals.2017.02.002

Sandberg, S. (2013). Lean in: Women, work and the will to lead. London: Random House.

Saunders, N. (2017). International political theory and the refugee problem (Routledge research on the global politics of migration). London: Routledge.

Savickas, M. L. (2005). The theory and practice of career construction. In S. D. Brown \& R. W. Lent (Eds.), Career development and counselling: Putting theory and research to work (pp. 42-70). Hoboken, NJ: John Wiley and Sons Inc.

Scotland, J. (2012). Exploring the philosophical underpinnings of research: Relating ontology and epistemology to the methodology and methods of the scientific, interpretive, and critical research paradigms. English Language Teaching, 5(9) 9-16. https://doi.org/10.5539/elt.v5n9p9

Shaik, N. (2016). Teachers' beliefs about child participation in Grade R. South African Journal of Childhood Education, 6(1), 1-10. http://doi.org/10.4102/sajce. v6i1.248
Smith, L. R. (2013). Female refugee networks: Rebuilding post-conflict identity. International Journal of Intercultural Relations, 37, 11-27. http://doi.org/ 10.1016/j.jintrel.2012.04.011

Taylor, C., Gibbs, G. R., \& Lewins, A. (2005). Quality of qualitative analysis. Retrieved from Learning Qualitative Data Analysis on the Web: http://onlineqda.hud.ac.uk/ Intro_QDA/qualitative_analysis.php.

Tharmaseelan, N., Inkson, K., \& Carr, S. C. (2010). Migration and career success: Testing a time-sequenced model. Career Development International, 15(3), 218-238. https://doi.org/10.1108/13620431011053712

Thornhill, H. L., Clare, L., \& May, R. (2004). Escape, enlightenment and endurance: Narratives of recovery from Psychosis. Anthropology and Medicine, 11, 181-199. https://doi.org/10.1080/13648470410001678677

United Nations High Comissioner of Refugees, United Nations Population Fund Agency \& Women's Refugee Commission. (2016). Initial assessment report: Protection risks for women and girls in the European Refugee and Migrant Crisis. Greece: United Nations High Comissioner of Refugees.

United Nations High Commission for Refugees. (2015). Worldwide displacement hits alltime high as war and persecution increase. Geneva: United Nations High Comissioner of Refugees. Retrieved from http://www.unhcr.org/news/latest/2015/6/558193896/ worldwide-displacement-hits-all-time-high-war-persecution-increase.html.

United Nations High Commission of Refugees. (2016). Initial assessment report Protection risks for women and girls in European Refugees and migrant crisis. Greece: United Nations High Comissioner of Refugees.

Vagenshtein, Y. F., \& Yemini, L. A. (2016). Migration, gender, and mobility: EthiopianIsraeli women's narratives of career trajectories, African and Black Diaspora. An International Journal, 9(2), 257-273. https://doi.org/10.1080/1758631.2015.1 083185

Willott, J., \& Stevenson, J. (2013). Attitudes to employment of professionally-qualified refugees in the UK. International Migration, 51(5), 120-132. https://doi. org/10.1111/imig.12038

Woodley, X. M., \& Lockard, M. (2016). Womanism and snowball sampling: Engaging marginalized populations in holistic research. The Qualitative Report, 21(2), 321-329.

Xie, B., Xia, M., Xin, X., \& Zhou, W. (2016). Linking calling to work engagement and subjective career success: The perspective of career construction theory. Journal of Vocational Behaviour, 94, 70-78. https://doi.org/10.1016/j.jvb.2016.02.011

Yakushko, O., Backhaus, A., Watson, M., Ngaruiya, K., \& Gonzalez, J. (2008). Career development concerns of recent immigrants and refugees. Journal of Career Development, 34(4), 362-396. https://doi.org/10.1177/0894845308316292

Yilmaz, K. (2013). Comparison of Quantitative and qualitative research traditions: Epistemological, theoretical, and methodological differences. European Journal of Education, 48(2), 311-324. https://doi.org/10.1111/ejed.12014 


\section{Appendix 1}

Interview guide:

1. Tell me about yourself. (Background information-education level and employment history; marital status; children; country of origin)

2. May you tell me about the circumstances that forced you to leave your home country? (When did you arrive in South Africa; why did you choose to come to South Africa)

3. What experiences and challenges did you face during your journey from your country of origin to South Africa?

4. Tell me a story of your arrival in South Africa, (Which border gate did you use to enter South Africa, did you know anyone in the country when you arrived?)

5. Did you receive assistance from the government or humanitarian organisations when you arrived? (What kind of assistance? explain how this assisted you?)

6. Did you encounter any challenges in adapting to the new environment? (How did you deal with the situations)

7. Tell me about your profession and career when you were in your home country.

8. Upon arrival, how long did it take you to get a job, did you get assistance from job agents? (What are some of the challenges that you encountered when looking for employment, is your current job in line with your area of expertise?)

9. Is the organisation that you are working for accommodative of refugees? (Did they play a role in the way you adjusted to the new environment?)

10. Tell me about the most stressful situation that you faced when you started working in South Africa and how you handled the situation?

11. In your own understanding, what is meant by the term career development? (What factors do you think influence career development)

12. Do you think women's career development is different from that of men? (Please tell me a story that explains why it is different)

13. Is your career developing as you anticipate? (What factors that are influencing the success of your career? what aspects are within your control and which are beyond your control?)

14. How do you think the government and organisations should assist with some of the challenges that you are facing? (What do you think should be done to help women refugees?) 